\title{
Graphene-Reinforced Titanium Enhances Soft Tissue Seal
}

\author{
Jianxu Weit, Shichong Qiaot, Xiaomeng Zhang, Yuan Li, Yi Zhang, Shimin Wei, \\ Junyu Shi* and Hongchang Lai*
}

Department of Oral and Maxillo-facial Implantology, Shanghai Ninth People's Hospital, School of Medicine, Shanghai Jiao Tong University, Shanghai, China

OPEN ACCESS

Edited by:

Kai Zheng,

University of Erlangen Nuremberg,

Germany

Reviewed by:

Annabel Braem,

KU Leuven, Belgium

Håvard Jostein Haugen,

University of Oslo, Norway

*Correspondence:

Hongchang Lai

hongchanglai@126.com

Junyu Shi

sakyamuni_in@163.com

${ }^{\dagger}$ These authors have contributed equally to this work

Specialty section:

This article was submitted to Tissue Engineering and Regenerative Medicine,

a section of the journal Frontiers in Bioengineering and Biotechnology

Received: 07 February 2021

Accepted: 24 March 2021

Published: 13 April 2021

Citation:

Wei J, Qiao S, Zhang X, Li Y,

Zhang $Y$, Wei S, Shi J and Lai H (2021) Graphene-Reinforced Titanium

Enhances Soft Tissue Seal.

Front. Bioeng. Biotechnol. 9:665305.

doi: 10.3389/fbioe.2021.665305
The integrity of soft tissue seal is essential for preventing peri-implant infection, mainly induced by established bacterial biofilms around dental implants. Nowadays, graphene is well-known for its potential in biocompatibility and antisepsis. Herein, a new titanium biomaterial containing graphene (Ti-0.125G) was synthesized using the spark plasma sintering (SPS) technique. After material characteristics detection, the subsequent responses of human gingival fibroblasts (HGFs) and multiple oral pathogens (including Streptococci mutans, Fusobacterium nucleatum, and Porphyromonas gingivalis) to the graphene-reinforced sample were assessed, respectively. Also, the dynamic change of the bacterial multispecies volume in biofilms was evaluated using absolute quantification PCR combined with Illumina high-throughput sequencing. Ti-0.125G, in addition to its particularly pronounced inhibitory effect on Porphyromonas gingivalis at $96 \mathrm{~h}$, was broadly effective against multiple pathogens rather than just one strain. The reinforced material's selective responses were also evaluated by a co-culture model involving HGFs and multiple strains. The results disclosed that the graphene-reinforced samples were highly effective in keeping a balance between the favorable fibroblast responses and the suppressive microbial growth, which could account for the optimal soft tissue seal in the oral cavity. Furthermore, the underlying mechanism regarding new material's bactericidal property in the current study has been elucidated as the electron transfer, which disturbed the bacterial respiratory chain and resulted in a decrease of microbial viability. According to the Kyoto Encyclopedia of Genes and Genomes (KEGG) database, the PICRUSt tool was conducted for the prediction of microbial metabolism functions. Consequently, it is inferred that Ti-0.125G has promising potentials for application in implant dentistry, especially in enhancing the integrity of soft tissue and improving its resistance against bacterial infections around oral implants.

Keywords: fibroblasts, bacteria, bioactive materials, peri-implant infections, sequencing

\section{INTRODUCTION}

The integrity of the soft tissue seal is vital for the long-term success of dental implants, which can prevent bacterial invasion and protect the underneath osseointegration. Nowadays, commercial pure titanium ( $\mathrm{Cp}-\mathrm{Ti}$ ) has been commonly used as a transmucosal component of the implant for decades due to its superior biocompatibility, corrosion resistance, and excellent mechanical properties (Yue et al., 2014). However, there are some burning questions demanding prompt 
solutions, such as $\mathrm{Cp}-\mathrm{Ti}$ weakly performs in bactericidal effect and soft tissue integration. These limitations make transmucosal applications of implants susceptible to the colonization of oral pathogens, which contribute to the high risks of peri-implant infection and even lead to implant failure (Mellado-Valero et al., 2013).

Graphene (Gr), a two-dimensional carbon material, has not only showed the potential of its excellent biocompatibility to various mammalian cells but also exhibited an ideal bactericidal characteristic to microorganisms (Sanchez et al., 2012; Jia et al., 2016). Currently, $\mathrm{Gr}$ is often introduced into titanium by coating techniques such as chemical vapor deposition. However, the benefit of the coating layer is paired with the risk of layer peeling due to the compromised adhesion strength between $\mathrm{Gr}$ and titanium surface ( $\mathrm{Gu}$ et al., 2018). Therefore, in order to tailor $\mathrm{Cp}$-Ti with favorable bactericidal property and fast gingival attachment, a novel Gr-reinforced titanium (Ti-0.125G) was fabricated using the spark plasma sintering (SPS) technique in our study, which made Gr evenly dispersed in titanium with a tight bond.

Various bacterial aggregated and formed as biofilms on the implant surface are often regarded as the prelude of peri-implant infection. Previous investigations mainly used one or two microbes to evaluate the antibacterial activity of biomaterials, which was limited to reflect the reality in nature (Pereira et al., 2015; Schmidt et al., 2016; Sridhar et al., 2016). Here, for evaluating Ti-0.125 G's antimicrobial property more precisely, we mimicked the oral condition and constructed a multispecies biofilm containing typical pathogens of peri-implantitis like Streptococci mutans (S. mutans), Fusobacterium nucleatum (F. nucleatum), and Porphyromonas gingivalis ( $P$. gingivalis). The dynamic changes of the bacterial multispecies biofilm were subsequently determined by absolute quantification PCR and 16S rRNA sequencing. In addition, although HGFs were mostly selected to assess the soft tissue attachment to biomaterials, the biomaterials' selective responses to bacteria and HGFs were often neglected. In this regard, a co-culture model involving the aforementioned pathogens and HGFs was established to evaluate the effect of Ti-0.125G on soft tissue seal. This model served as a better mimicry accounting for a "race-for-the-surface" between the bacterial multispecies and HGFs in the transmucosal region (Zhao et al., 2014).

Herein, a novel Ti-0.125G was fabricated by the SPS technique and aimed to be the emergence profile component for implants. The antibacterial activity of the Ti-0.125G against the above multiple pathogens was assessed by morphological observation, live/dead fluorescent staining, spread plate test, and Illumina high-throughput sequencing. Also, the soft tissue responses to Ti-0.125G were evaluated in vitro. The selective response of the Gr-reinforced sample was assessed by the co-culture model containing HGFs and the pathogenic multispecies. Besides, an attempt has been made to explain the underlying mechanism of Ti-0.125 G's bactericidal property. Ti-0.125G has a promising antibacterial potential and it may have a wide range of clinical applications in promoting soft tissue integration (Supplementary Appendix Scheme).

\section{MATERIALS AND METHODS}

\section{Sample Preparation}

Commercially pure titanium (Cp-Ti) powder (average diameter $30 \mu \mathrm{m}$, sphere-like, Grade IV) and graphene powder were obtained from the Institute of Solidification Science and Technology, Shanghai Jiao Tong University. For mixing graphene powder with Ti powder uniformly, we firstly added graphene powder into anhydrous ethanol (Sigma-Aldrich, United States) and performed $2-3 \mathrm{~h}$ ultrasonic dispersion. After 1,000-1,500 r/min magnetic stirring and 100-200 r/min ball-milling, the $\mathrm{Ti} / \mathrm{Gr}$ composite powder (particle size of 10-60 $\mu \mathrm{m}$ ) was eventually obtained through 240-mesh sieves. Next, spark plasma sintering (SPS) was carried out in the vacuum environment at $900^{\circ} \mathrm{C}$ and $50 \mathrm{MPa}$ to obtain disk-shaped samples (10 $\mathrm{mm}$ diameter, $1 \mathrm{~mm}$ thickness). Then the disks were polished with $\mathrm{SiC}$ paper (150 rpm, $20 \mathrm{~N}$, EcoMet 30, Buehler, Germany), and washed with anhydrous ethanol, acetone (Sigma-Aldrich, United States), and de-ionized (DI) water sequentially (30 min each) in an ultrasonic bath. The control and the test groups were labeled as Cp-Ti and Ti-0.125G, respectively.

\section{Characterization of the Sample}

The surface morphology of samples was detected using a scanning electron microscopy (SEM; ZEISS Gemini 300). The surface chemical characteristic was roughly detected by analyzing 10 points dispersed on the materials' surfaces using energy dispersive spectroscopy (EDS; OXFORD Xplore). The points on $\mathrm{Cp}$-Ti were chosen randomly while they were elaborately picked out on Ti-0.125G, including the points inside and outside the graphene-like aggregates (which appeared black under SEM observation), as well as those on the boundary lines $(N=10)$. The phase transformation of the material was detected using X-ray diffraction (XRD; rigaku Ultima IV, Japan) patterns at a step size of $0.02^{\circ}$ in a $2 \theta$ range of $20-80^{\circ}(30 \mathrm{kV}$, $20 \mathrm{~mA})$. The morphology of graphene was semi-quantitatively determined by Raman spectroscopy ( $\lambda=532 \mathrm{~nm}$, LabRAM HR Evolution, Horiba France SAS). The surface hydrophilicity was examined using a water contact angle measurement (DSA100, Kruss). The nano-hardness and elastic modulus of samples were characterized using a nano-indentation test (Agilent Tech, Nano Indenter G200). The surface roughness values involving $\mathrm{Ra}$ and Rq were determined using an atomic force microscopy (AFM; Nanonavi E-Sweep). The current-voltage (I-V) characteristics of specimens were obtained using an electrochemical analyzer (Reference 3,000, Gamry) with suitable voltage (-6-6 V) at the frequency of $100 \mathrm{mV} / \mathrm{s}$. The material's electrochemical characteristics including Mott-Schottky curve were evaluated using an electrochemical system (VersaSTAT 3F, Ametek), and artificial saliva (A7990, Solarbio) was used as the liquid environment for testing.

\section{Bacterial Multispecies Culture}

Some typical oral pathogens, including gram-positive Streptococcus mutans (S. mutans; UA159), gram-negative Fusobacterium nucleatum (F. nucleatum; ATCC25586), and 
Porphyromonas gingivalis ( $P$. gingivalis; ATCC33277), were cultured in the brain heart infusion (BHI) broth medium (BD) under standard anaerobic conditions $\left(80 \% \mathrm{~N}_{2}, 10 \% \mathrm{H}_{2}\right.$, and $10 \%$ $\mathrm{CO}_{2}$ at $37^{\circ} \mathrm{C}$ ). Pathogens were harvested during the exponential growth phase for further use.

\section{Bacterial Multispecies Morphology}

After incubated with microorganisms for 24 and $48 \mathrm{~h}$, all samples were fixed with $2.5 \%$ glutaraldehyde overnight at $4^{\circ} \mathrm{C}$. All samples were dehydrated in a series of the ethanol concentration gradient of $30,50,75,90$, and $100 \mathrm{v} / \mathrm{v} \%$ (aq.), and then were freeze-dried, coated with gold, and observed using SEM.

\section{Live/Dead Staining of Bacterial Multispecies}

After incubating for 6 and $24 \mathrm{~h}$, the biofilms on specimens were stained with Live/dead ${ }^{\circledR}$ BacLight $^{\mathrm{TM}}$ bacterial viability kit solution (Invitrogen). The 1:1 fluorochrome ratio of $10 \mathrm{~min}$ reacting time provided the optimum fluorescence effects. Consequently, the intact bacteria were stained fluorescent green, while the non-viable ones with compromised membranes were stained fluorescent red.

\section{Spread Plate Test}

The spread plate test demonstrated the antibacterial property during a period $(6,12,24$, and $48 \mathrm{~h})$. In detail, $500 \mu \mathrm{L}$ mixed bacterial suspension (containing $\sim 10^{6} \mathrm{CFU} / \mathrm{mL}$ S. mutans, $\sim 10^{7} \mathrm{CFU} / \mathrm{mL}$ F. nucleatum, and $\sim 10^{7} \mathrm{CFU} / \mathrm{mL}$ P. gingivalis) was added to the glass disk (the blank). Each sample was placed in a 24-well plate to establish the biofilm. Then the adherent bacterial multispecies were collected in an ultrasonic bath (KQ5200E, $200 \mathrm{~W}$, and $50 \mathrm{~Hz}$ ) after vortexing. After that, $100 \mu \mathrm{L}$ solution was evenly spread on the sheep blood agar dish with a sterile cell spreader. After being incubated in the anaerobic condition, colonies of multi-bacteria were counted. The relative colony-forming units [RCFU (\%)] and the antibacterial rates [Ra (\%)] were analyzed by the following equations:

RCFU $(\%)=(\mathrm{CFU}$ of $\mathrm{Cp}-\mathrm{Ti}$ or $\mathrm{Ti}-0.125 \mathrm{G}) / \mathrm{CFU}$ of the blank $\times 100 \%$

$\mathrm{Ra}(\%)=(\mathrm{CFU}$ of the control-CFU of the reinforced sample)/CFU of the control $\times 100 \%$

\section{Bacterial Biofilm Susceptibility and Viability Assay}

Crystal violet (CV) staining and the 3-(4,5-dimethylthiazolyl2)-2,5-diphenyltetrazolium bromide (MTT) test were used to investigate the bactericidal effect of materials on the formed biofilms. In the beginning, $500 \mu \mathrm{L}$ BHI medium involving multispecies $\left(\sim 10^{6} \mathrm{CFU} / \mathrm{mL}\right.$ S. mutans, $\sim 10^{7} \mathrm{CFU} / \mathrm{mL}$ $F$. nucleatum, and $\sim 10^{7} \mathrm{CFU} / \mathrm{mL} P$. gingivalis) was added on the samples pre-placed in a 24-well plate to develop the biofilms. As for the biofilm susceptibility assay, after incubating for 12, 24 , and $48 \mathrm{~h}$, the supernatant was carefully aspirated, and the contaminated samples were rinsed and then fixed with methanol for $15 \mathrm{~min}$ at RT. After stained with CV for $10 \mathrm{~min}$, the biofilmdisk complex was washed and dried overnight. The stained biofilm was dissolved with 95\% ethanol and its absorbance was recorded at $550 \mathrm{~nm}$ wavelength. As for viability assay, after incubating with $0.5 \mathrm{mg} / \mathrm{mL}$ MTT for $2 \mathrm{~h}$, the solution was gently decanted before DMSO was added to dissolve the formazan crystals. The absorbance was recorded at $490 \mathrm{~nm}$ wavelength.

\section{Absolute Quantification of Bacterial Multispecies}

Absolute quantification PCR (AQ-PCR) was conducted to illustrate the biomasses of bacterial multispecies quantitatively in a well-established biofilm After washed with phosphate-buffered saline (PBS; Sigma) to remove the non-adherent colonies. The biofilms were isolated using a $10-\mathrm{min}$ ultrasonic bath at RT. According to the manufacturer's instructions, the total DNA extraction was performed using a DNA isolation kit (Omega). After preparing the mixture solution containing DNA, F-/Rprimers, and signaling SYBR Green probe (Vazyme, Q11202 ), the samples were reacted sequentially under the initial amplification cycle of $95^{\circ} \mathrm{C}$ for $5 \mathrm{~min}$, followed by 40 cycles at $95^{\circ} \mathrm{C}$ for $15 \mathrm{~s}$ and $60^{\circ} \mathrm{C}$ for $30 \mathrm{~s}$. Gene expressions were analyzed by corresponding quantification cycle $(\mathrm{Cq})$ values. The primers used in this assay were listed in Table $\mathbf{1}$ and were commercially synthesized (Personalbio Co., Ltd., Shanghai). The final result (the absolute quantity (X0) of each colony) was obtained according to the following correlation: $\mathrm{Cq}=-\mathrm{K} \log \mathrm{X} 0+\mathrm{b}$. The disposal was repeated in triplicate to ensure repeatability.

\section{Illumina 16S rRNA Sequencing of Bacterial Multispecies}

Herein, a $10 \mathrm{~mm} \times 1 \mathrm{~mm}$ glass disk was regarded as the blank group due to its insulative characteristic compared to the metal disks, excluding the potential electrochemical interferences. The universal reaction of $\mathrm{V} 3-\mathrm{V} 4$ regions of the bacterial $16 \mathrm{~S}$ rRNA genes was amplified by $338 \mathrm{~F} / 806 \mathrm{R}$ primers. PCR was conducted according to the previous instructions (Cheng et al., 2019). The unprocessed data was obtained after the first sequencing with an Illumina Miseq sequencing platform (PE300, Personalbio). After the process of quality control, the resulting sequences were clustered into amplicon sequence variants (ASVs) at a $100 \%$ similarity using Quantitative Insights Into Microbial Ecology 2 (QIIME2) dada2 clustering. Diagrams were produced with various aspects based on the abundance of ASVs combined with a set of multivariate analyzing tools. A prediction of microbial metabolism functions was provided using PICRUSt (Phylogenetic Investigation of Communities by Reconstruction

TABLE 1 | The prime sequences of bacteria in absolute quantification PCR.

\begin{tabular}{llc}
\hline Species & Sequence $\left(\mathbf{5}^{\prime}\right.$ to $\left.\mathbf{3}^{\prime}\right)$ & Amplicon size (bp) \\
\hline S. mutans & F: GCCTACAGCTCAGAGATGCTATTC & 118 \\
& R: GCCATACACCACTCATGAATTGA & \\
F. nucleatum & F: CAGCTTGCCATACTGCG & 404 \\
& R: ACTGTTAGCAACTACCGATGT & 182 \\
P. gingivalis & F: GGCCACAAGGGGACTGAGACA & \\
& R: TITAGCCGTCACTTCTTCTGTTGG
\end{tabular}


of Unobserved States) tools according to the Kyoto Encyclopedia of Genes and Genomes (KEGG) database.

All 16S sequencing data on gene expressions have been deposited in NCBI's Sequence Read Archive (SRA) and are accessible through accession number PRJNA707007¹.

\section{HGFs Culture}

The primary HGFs were obtained from the healthy gingival tissue blocks clinically. All protocols related to humans in this study were approved by the Independent Ethics Committee of Shanghai Ninth People's Hospital affiliated to Shanghai Jiao Tong University School of Medicine (YBKA201906). The gingival tissues were harvested from young adults (18-35 years old, $n=5)$ during oral implant surgeries and cut into fragments with sterile scissors. Then the fragments were covered by glass slices in a $9 \mathrm{~cm}$ dish (Corning) and damped with Dulbecco's modified Eagle medium (DMEM; Sigma) containing 10\% fetal bovine serum (FBS; Gibco) and $100 \mathrm{U} / \mathrm{mL}$ penicillin/streptomycin and $2 \mathrm{mM}$ glutamine at $37^{\circ} \mathrm{C}$ in a standard humidified incubator. Primary HGFs were isolated 2 weeks later, and passages 2-7 were used in this study.

\section{HGFs Morphology on the Sample}

For investigating the morphology of adherent cells, SEM analysis was employed. Briefly speaking, HGFs of $1 \times 10^{4}$ cells per well were seeded on the samples on a 24 -well plate. After 1 and $6 \mathrm{~h}$ of incubation, the samples were transferred to a new plate and fixed in $2.5 \%$ glutaraldehyde overnight at $4^{\circ} \mathrm{C}$. The samples were dehydrated sequentially using ethanol solution with concentrations of $30,50,75,90$, and $100 \mathrm{v} / \mathrm{v} \%$ (aq.). Then, the samples were placed in hexamethyldisilazane (HMDS) ethanol solutions and freeze-dried overnight. All samples were sputtercoated with gold before further characterization. Measurements were conducted thrice.

Morphologic details of HGFs were also observed using the confocal laser-scanning microscope (CLSM; Leica). The cells $\left(1 \times 10^{4}\right.$ cells/well $)$ were seeded on the disks in a 24 -well plate. At 6 and $24 \mathrm{~h}$, the samples were rinsed twice with PBS, followed by fixed with $4 \%$ paraformaldehyde (PFA) and permeabilized with $0.1 \%$ Triton X-100. Then, the cellular cytoskeletons and nuclei were sequentially stained with phalloidin and DAPI (Invitrogen), respectively. The disposals followed the protocol provided by the manufacture.

\section{HGFs Adhesion and Proliferation}

$5 \times 10^{4}$ Fibroblasts per well were cultured with the samples for 1,4 , and 7 days in 24-well plates. After being washed, the specimens were incubated with $500 \mu \mathrm{L}$ of DMEM plus $50 \mu \mathrm{L}$ of CCK- 8 solution for $1 \mathrm{~h}$ at $37^{\circ} \mathrm{C}$. The absorbance of the solution was recorded at $490 \mathrm{~nm}$ wavelength following the manufacturer's instructions. Besides, cell nuclei fluorescing with DAPI were detected under CLSM detection, and the disposal followed the aforementioned instructions.

${ }^{1}$ https://www.ncbi.nlm.nih.gov/sra/

\section{HGFs Migration}

The following experiments detected the migration property of HGFs on different surfaces horizontally and vertically. In wound healing assay, HGFs were grown on the samples overnight with a density of $1 \times 10^{6}$ cells per well until the cells reached confluence. Then, the cell monolayer was wounded carefully with a plastic pipette. After culturing for an additional 0, 6, and $24 \mathrm{~h}$, the cell-disk complex was transferred to another plate and fixed in $4 \%$ PFA at each time point. Next, $0.1 \%$ Triton X-100 was used to permeate the cell membrane for $10 \mathrm{~min}$. Similarly, DAPIstained cell nuclei were visualized under CLSM. In fluorescence images, the original wounded region, namely, the area between each border of the monolayer was measured, so as to calculate the number of the migrated cells stained blue in the wounded areas.

In the transwell experiment, 0.4-mm-micropore transwell inserts (Corning Costar, Lowell, MA, United States) were placed upon the samples, which were pre-placed in a 24-well plate. First, HGFs were trypsinized and diluted with serum-free medium. Then, $750 \mu \mathrm{L}$ DMEM with FBS was added in equal quantity to the lower chamber before $200 \mu \mathrm{L}$ cell suspension (containing $2 \times 10^{5}$ cells $/ \mathrm{mL}$ ) was pipetted into the inner chamber. The cells were incubated for $12 \mathrm{~h}$ and fixed in $4 \%$ formaldehyde solution. Before being stained with $0.1 \mathrm{w} / \mathrm{v} \% \mathrm{CV}$, the cells were permeabilized with $100 \%$ methanol at RT. The images of migrated cells were finally recorded under a light microscope (Leica).

\section{qRT-PCR Analysis of HGFs}

The total RNA was extracted using the total RNA isolation kit (Omega), then cDNA was generated using the PrimeScript 1st Strand cDNA synthesis kit (TaKaRa). Analyses were performed using the LightCycler 480 II thermocycler (Roche). The primers in this study were synthesized commercially (Shenggong). The corresponding genes and primer sequences were listed in Table 2.

\section{Western Blot}

HGFs were trypsinized and lysed with a protein extraction reagent. The concentration of protein was recorded sequentially using the Bradford Kit (Beyotime) and the microplate

TABLE 2 | Primer pairs of HGFs in real-time PCR analysis.

\begin{tabular}{ll}
\hline Gene & Primers (F = Forward, $\mathbf{R}=\mathbf{R e v e r s e )}$ \\
\hline VCL & F: CGAATCCCAACCATAAGCAC \\
ITGB1 & R: GCCGACTTCCTTCACCATAG \\
& F: TGGAGGAAATGGTGTTGC \\
FAK & R: CGTTGCTGGCTTCACAAGTA \\
& F: CTCCTACTGCCAACCTGGAC \\
FN1 & R: GCCGACTTCCTTCACCATAG \\
& F: GACCGAAATCACAGCCAGTAG \\
COL1A1 & R: CATCTCCCTCCTCACTCAGC \\
& F: AAGACATCCCACCAATCACC \\
GAPDH & R: CGTCATCGCACAACACCTT \\
& F: TGTGTCCGTCGTGGATCTGA \\
& R: TTGCTGTTGAAGTCGCAGGAG
\end{tabular}



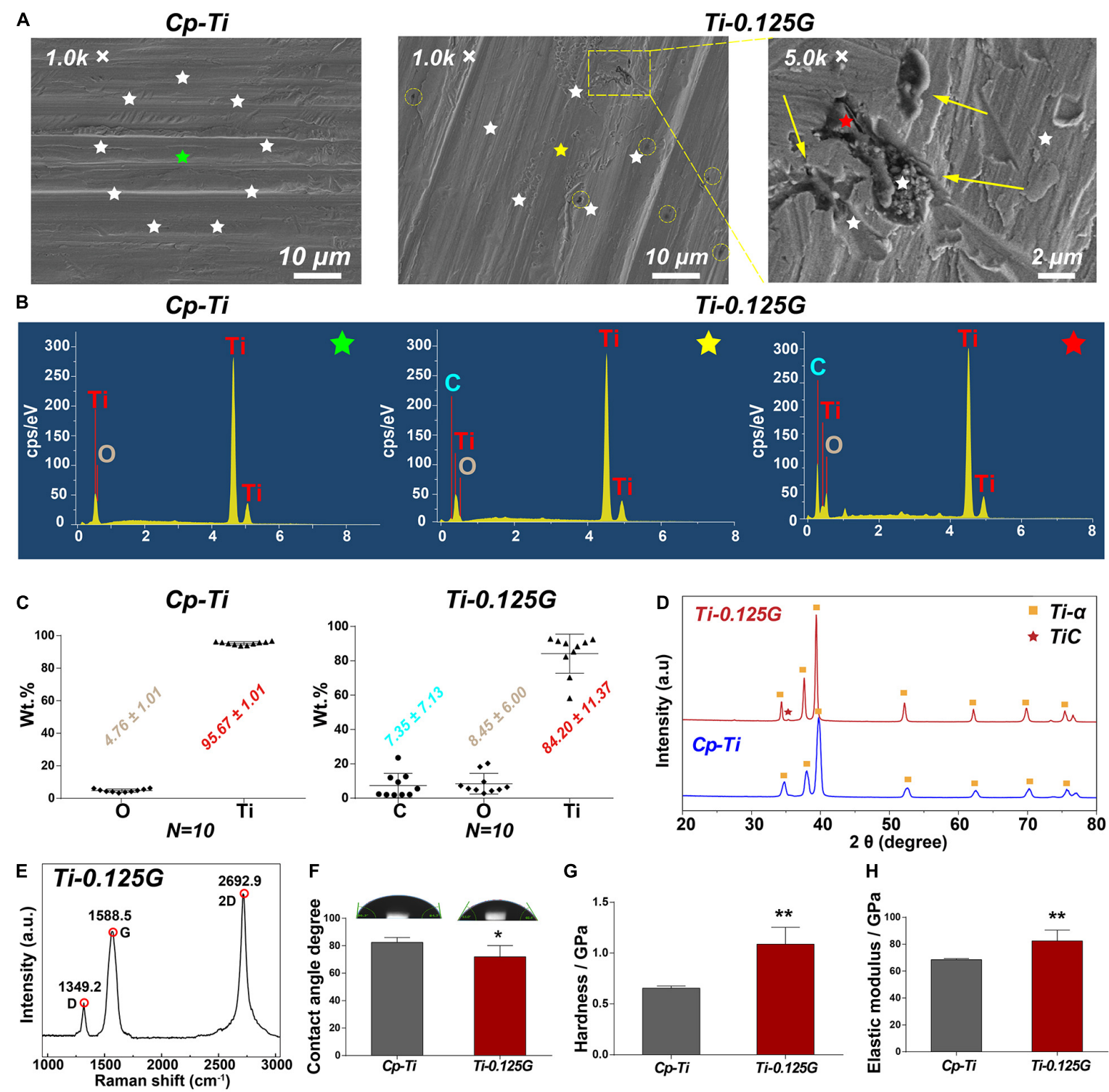

G
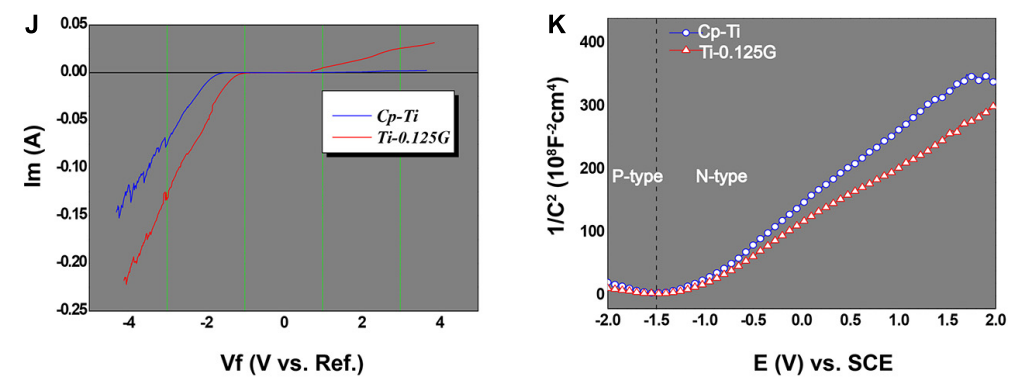

FIGURE 1 | Characterization of the sample. (A) SEM micrographs of the samples at different magnification. For the group of Ti-0.125G, the colored circles indicated the distribution of graphene aggregates at $1.0 \mathrm{~K} \times$ magnification (scale bar $=10 \mu \mathrm{m}$ ), and the arrows marked the agglomerated graphene at $5.0 \mathrm{~K} \times$ magnification (scale bar $=2 \mu \mathrm{m}$ ). (B) The respective EDS points' spectra of $\mathrm{Cp}-\mathrm{Ti}$ (green-starred) and Ti-0.125G (the point outside the Gr-like aggregate marked as a yellow star and the point inside the Gr-like aggregate marked as a red star). (C) The elemental concentrations of $\mathrm{C}, \mathrm{Ti}$, and $\mathrm{O}$ were measured by EDS semi-quantitative technique (expressed as average \pm standard deviation; $N=10$ ). (D) XRD patterns of Cp-Ti and Ti-0.125G $\left(2 \theta=20-80^{\circ}\right)$. (E) Raman spectra of Ti-0.125G.

(F) Wettability analysis $\left({ }^{*} p<0.05\right)$. (G,H) Elastic modulus and nano-hardness analyses $\left({ }^{* *} p<0.01\right)$. (I) Surface roughness. No significant differences in Ra and Rq values. (J) The current-voltage (I-V) characteristics. (K) The conductivity type was depicted by the Mott-Schottky curves. 
spectrophotometer (Bio-Tek, Epoch 2) at $595 \mathrm{~nm}$ wavelength. Proteins $(20 \mu \mathrm{g})$ were loaded and then electro-transferred to a polyvinylidene difluoride (PVDF) membrane, which was incubated subsequently with specific primary antibodies as previously described (Wang X. et al., 2016). Ultimately,the protein bands were quantified using the imaging system (Vilber, Fusion Pulse 6).

\section{The Co-culture Model of Bacterial Multispecies and HGFs}

Three species (UA159, ATCC33277, and ATCC25586) and HGFs were sequentially seeded on the samples. $25 \mu \mathrm{L}$ bacterial suspension [containing $\sim 10^{4}$ colony-forming units (CFU)/mL S. mutans, $\sim 10^{5} \mathrm{CFU} / \mathrm{mL}$ F. nucleatum and $\sim 10^{5} \mathrm{CFU} / \mathrm{mL}$ $P$. gingivalis] was pipetted on the disks in a 24 -well plate and cultured anaerobically for $90 \mathrm{~min}$, yielding the volume of $1 \times 10^{4} \mathrm{CFU} / \mathrm{cm}^{2}$ on the specimens (Wang J. et al., 2016). The modified medium (MM) containing $\sim 10^{4}$ HGFs was distributed into each well and incubated aerobically for 6 and $24 \mathrm{~h}$ at $37^{\circ} \mathrm{C}$. Specifically, MM was composed of DMEM with 10\% FBS and 2\% BHI (Foss et al., 2015), both of which were crucial in a balance without benefiting either the cells or the microbes at significant advantages. Bovine serum was added into MM and functionalized as the crevicular fluid surrounding dental implants. At each time point, HGFs were fixed and stained with phalloidin and DAPI, and their morphologies were visualized using CLSM.

\section{Statistics}

All data were presented as mean \pm standard deviation of at least three independent experiments. The data were statistically analyzed by one-way ANOVA. $P<0.05$ was regarded as significant.

\section{RESULTS}

\section{Characterization of the Sample}

We first characterized some key parameters of the Gr-reinforced Ti after the fabrication by the SPS technique. In SEM images, the surface morphology of the two groups seemed to be quite similar except for some black dots existed on Ti-0.125G surface. These dots were like multi-layer graphene aggregates at high magnification (Figure 1A). In contrast to the random emission for the $\mathrm{Cp}$-Ti group, the $\mathrm{X}$-rays for the $\mathrm{Ti}-0.125 \mathrm{G}$ group were designedly emitted to the Gr-like aggregates (black), the surrounding areas (gray) and their boundary lines without overlapping $(N=10)$. The EDS spectra (starred in Figures 1A,B) noted that $\mathrm{C}$ peak was unique in the spectrum of the Ti-0.125G compared to the $\mathrm{Cp}$-Ti. And $\mathrm{C}$ peak seemed to exhibit a larger and higher shape since the $\mathrm{X}$-ray emission targeted the graphenelike aggregate rather than the surroundings. Also, depending on the 10-point EDS results, we ultimately indicated that the elemental concentrations of the groups were analyzed as $\mathrm{O}$ and $\mathrm{Ti}$ accounting for $4.76 \pm 1.01 \mathrm{Wt} . \%$ and $95.67 \pm 1.01 \mathrm{Wt} . \%$, respectively, in $\mathrm{Cp}$ - $\mathrm{Ti}$ and $\mathrm{C}, \mathrm{O}$, and $\mathrm{Ti}$ accounting for $7.35 \pm 7.13$ Wt.\%, $8.45 \pm 6.00 \mathrm{Wt} . \%$, and $84.20 \pm 11.37 \mathrm{Wt} . \%$, respectively, in Ti-0.125G (Figure 1C). Figure 1D showed the phase and structure of the $\mathrm{Cp}$-Ti and Ti-0.125G. The XRD patterns of the two groups were similar, and the data were well matched with the International Centre for Diffraction Data (ICDD) reference cards. While Ti-0.125G had a narrow $\mathrm{Ti}$ peak at $2 \theta$ degree of 39.38 (No. 03-065-9622), which was indexed into the C (101) of multi-layer graphene. Furthermore, the peak intensity of Ti$\alpha / \mathrm{Gr}$ at $34.34^{\circ}$ and $37.64^{\circ}$ was higher than the pure $\mathrm{Ti}-\alpha$ peaks due to the presence of $\mathrm{Gr}$. The peak $2 \theta=35.34^{\circ}$ (Ti- $\mathrm{C}$ peak) indicated graphene existed in the reinforced composites after SPS. Furthermore, the Raman spectrum of Ti-0.125G contained three prominent peaks near $1,349.2,1,588.5$, and $2,692.9 \mathrm{~cm}^{-1}$, corresponding to the D, G, and 2D bands of graphene (Fu et al., 2017; Figure 1E).

Moreover, the wettability data showed that water droplets spread more widely on Ti-0.125G with smaller contact angles values compared to $\mathrm{Cp}-\mathrm{Ti}\left(71.95^{\circ} \pm 3.32^{\circ}<82.47^{\circ} \pm 1.48^{\circ}\right.$; $p<0.05)$. The values of Ti-0.125G in elastic modulus and the hardness were significantly higher as compared to the control ( $p<0.01$; Figures $\mathbf{1 G}, \mathbf{H})$. The roughness of the two materials showed no significant differences using AFM detections (Figure 1I). In terms of the electrochemical characteristics, when the voltage was -1 volt, the electron flow through both samples ceased $(I=0)$. As the voltage increased, a thicker oxide membrane such as titanium dioxide was built upon the CpTi to block the electron flow further, which in contrast to the rising current through Ti-0.125G (Figure 1J). The Mott-Schottky curves demonstrated that Ti-0.125G was more electricallyconductive as its carriers were denser than those of $\mathrm{Cp}-\mathrm{Ti}$ (Figure 1K).

\section{Bactericidal Ability of the Sample}

Bacteria of the exponential growth phase were utilized in the study (Supplementary Appendix Figure 1). From a microperspective, $S$. mutans, F. nucleatum, and $P$. gingivalis exhibited distinct cell shapes on $\mathrm{Cp}-\mathrm{Ti}$ such as long-chain, long-rod, and short-rod after incubated for 24 and $48 \mathrm{~h}$. Adversely, on the surface of Ti-0.125G, S. mutans showed impaired shapes with the flux of intracellular contents, F. nucleatum transformed to shorter rod-like structures, and a dozen of $P$. gingivalis remained hardly intact with the collapsed structures (Figure 2A). The fluorescent result depicted that Ti-0.125G decreased multispecies quantitatively compared to Cp-Ti (Figure 2B). From a macro-perspective, the spread plate test indicated that Ti-0.125G exhibited a stronger antimultispecies potency by largely decreasing the number of CFU from 12-96 h (Figure 2D, $p<0.01$ ). Moreover, Ti$0.125 \mathrm{G}$ resisted the formation and viability of multispecies biofilm noticeably since it was well-established (Figures $\mathbf{2 G}, \mathbf{H}$; He et al., 2017).

\section{Quantitative and Proportional Analyses of Bacterial Multispecies}

Streptococci mutans, the early colonizer of pathogenic multispecies biofilm, decreased substantially in the blank from 12-96 h. F. nucleatum, the later colonizers, increased 

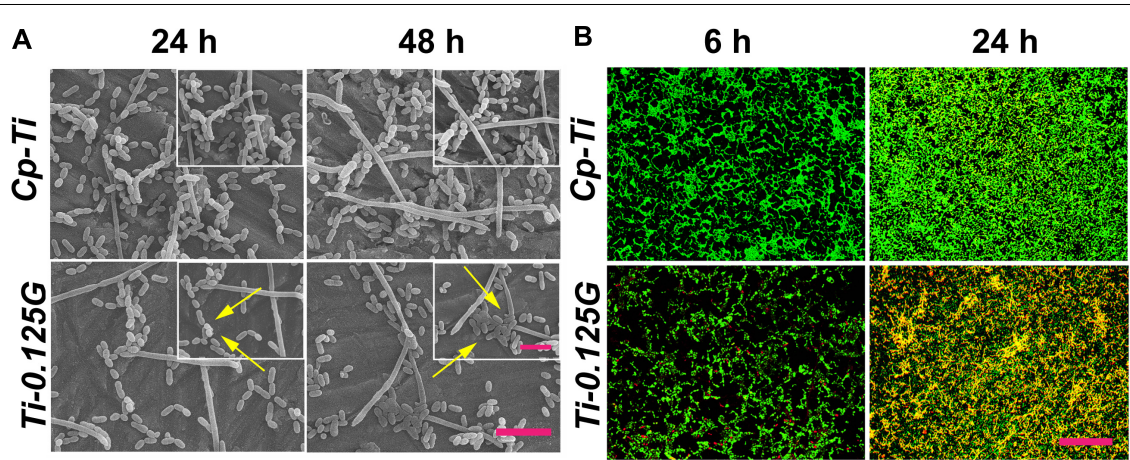

C
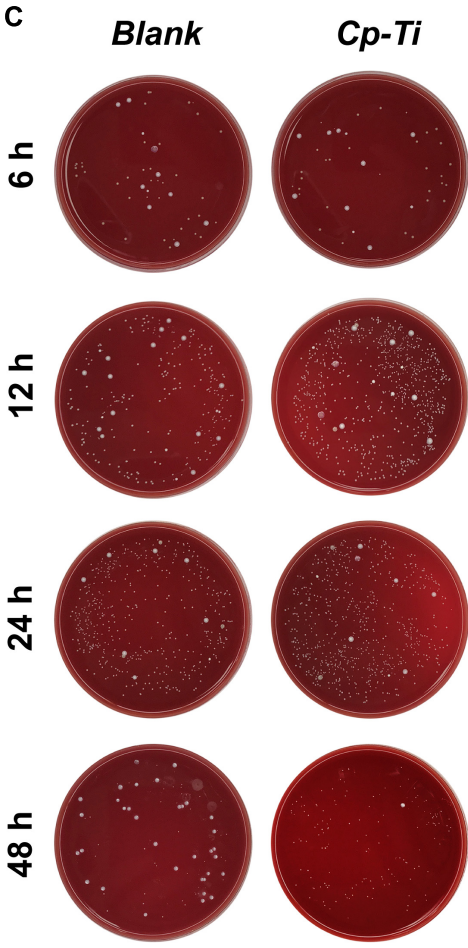

$\mathbf{F}$

$12 \mathrm{~h}$

$24 \mathrm{~h}$

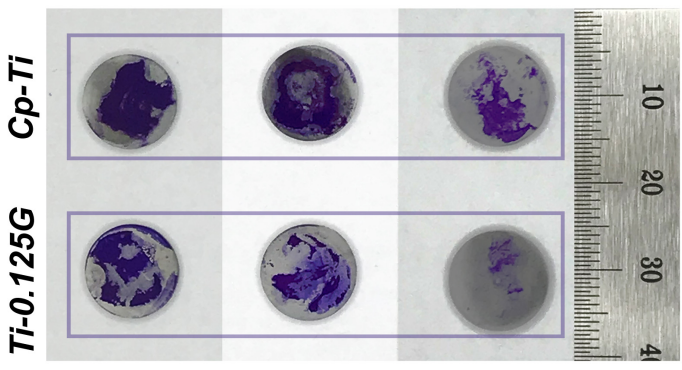

Ti-0.125G

D

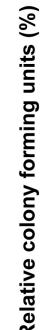

:

E

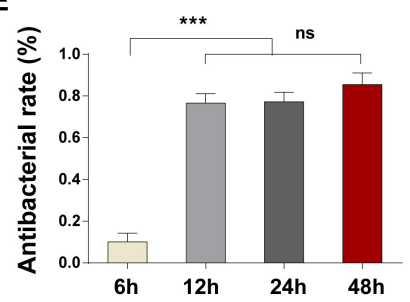

G
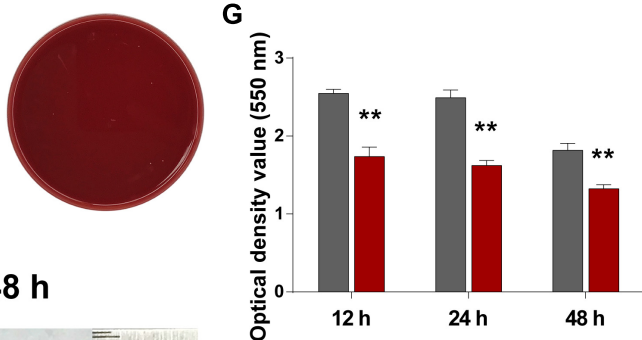

H

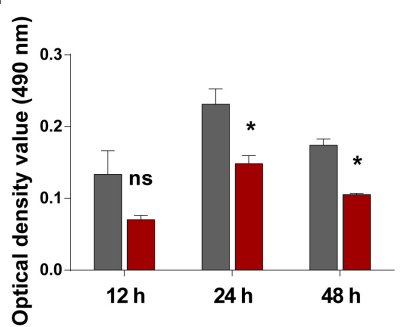

FIGURE 2 | The effects of samples against bacterial multispecies. (A) SEM micrographs of multiple bacteria on different samples after 24 and $48 \mathrm{~h}$ of incubation. Scale bar $=5 \mu \mathrm{m}$. The top right corner insert showed high magnification images (abnormal shapes of microbes were marked by white arrows). Scale bar for inserts $=2 \mu \mathrm{m}$. (B) CLSM images of bacterial multispecies cultured on different samples for 6 and $24 \mathrm{~h}$. All microbial cells were stained with two well-described probes, interpreting live bacteria (green) and dead ones (red). Scale bar $=50 \mu \mathrm{m}$. (C) Typical images of re-cultured pathogens (containing S. mutans, F. nucleatum, and $P$. gingivalis) colonies on each substrate after $6,12,24$, and $48 \mathrm{~h}$ of incubation. (D) and (E) Statistical results of relative CFUs and antibacterial rates of all groups. Noted that Ti-0.125G was the most effective in anti-bacteria after $6 \mathrm{~h}$ of interaction. ${ }^{\star \star} p<0.01,{ }^{* \star *} \mathrm{p}<0.001$. (F) Measurements of biofilm's biomass by $\mathrm{CV}$ staining at 12,24 , and $48 \mathrm{~h}$ of incubation. Scale bar was supplemented. (G) The statistical analysis noted that Ti-0.125G significantly inhibited bacterial multispecies biofilm. ${ }^{\star \star} p<0.01$. (H) Statistical analysis of MTT assay noted that Ti-0.125G reduced the viability of bacterial biofilms after 24 and $48 \mathrm{~h}$ of incubation. ${ }^{*} p<0.05$. 


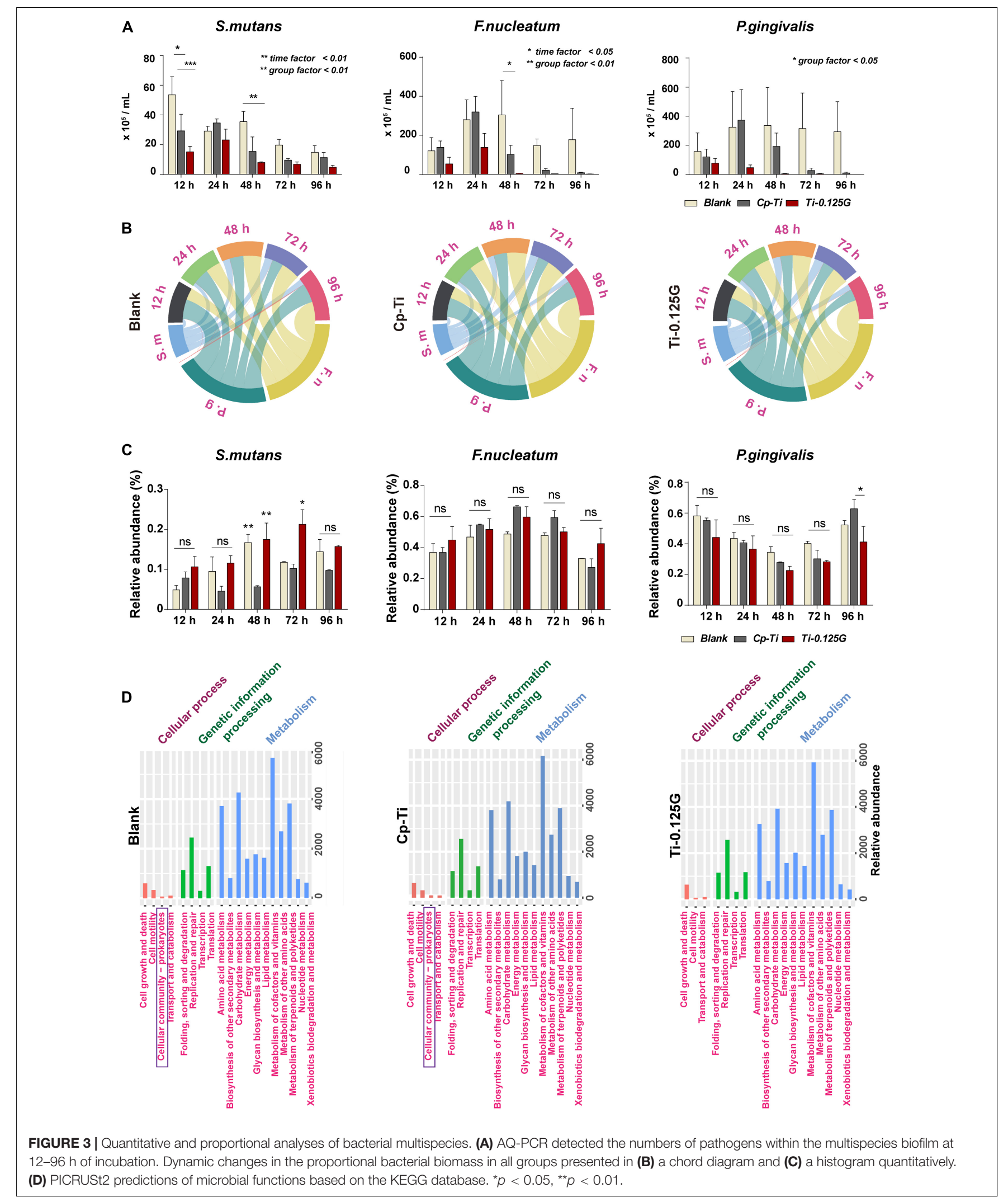


in all groups from $12-24 \mathrm{~h}$ and grew to a maximum at $24 \mathrm{~h}$ synchronously, then showed a downward tendency in Cp$\mathrm{Ti}$ and $\mathrm{Ti}-0.125 \mathrm{G}$ from 48-96 h (Figure 3A). Reportedly, bacterial multispecies biofilm reached peak viability around implants at $96 \mathrm{~h}$ (Bermejo et al., 2019). However, Ti-0.125G highlighted its bactericidal effect with the lowest biomasses of all strains after $96 \mathrm{~h}$ of interaction (Table 3). According to the proportional analyses, Ti-0.125G showed the most significant resistance against $P$. gingivalis, a principal etiological agent of implant infection (Zhu et al., 2019), with the thinnest arch in chord diagrams at $96 \mathrm{~h}$ (Figure 3B). Additionally, it was indicated that Ti-0.125G did not specifically target a particular strain except inhibiting $P$. gingivalis at $96 \mathrm{~h}$ compared to $\mathrm{Cp}-\mathrm{Ti}$ (Figure 3C and Supplementary Appendix Figure 2). In light of Ti-0.125 G's favorable bactericidal effect, the mechanism may be relevant to cellular processes based on the KEGG database.

\section{HGFs Responses to the Sample}

A series of cellular responses including morphology, adhesion, proliferation, and migration on the sample were investigated in Figure 4. Initially, HGFs exhibited spherical morphologies on $\mathrm{Cp}-\mathrm{Ti}$, compared to the varied morphologies with minimal spread on Ti-0.125G. $6 \mathrm{~h}$ later, HGFs spread larger with multipolar spindle shapes on Ti-0.125G, resulting in a higher value of $\mathrm{Ma} / \mathrm{Mo}$ elongation $(p<0.01)$. The similar morphologies were visualized by fluorescent staining on the Gr-reinforced sample (Supplementary Appendix Figure 3). Both at 6 and $24 \mathrm{~h}, \mathrm{HGF}$ adhered and increased densely on Ti-0.125G as compared to $\mathrm{Cp}-\mathrm{Ti}(p<0.05)$. In addition, Ti-0.125G exerted more potential to promote HGFs proliferation by extending the incubation time to 4 and 7 days (Figure $4 \mathrm{E}, p<0.01$ ). After interacted for $24 \mathrm{~h}$, the horizontal and vertical migration capabilities of HGFs were triggered significantly by Ti-0.125G (Figures 4F,H, $p<0.01$ ). Herein, Gr-reinforced sample sparked the HGFs' responses may be due to the increased expressions of adhesion-related genes (VCL, ITGB1, and FAK) and extracellular matrix (ECM) component-related genes (FN1 and COL1A1) at 6 and $24 \mathrm{~h}(p<0.05)$. Moreover, the expression of $\mathrm{p}$-FAK was activated with a higher ratio of $\mathrm{p}-\mathrm{FAK} / \mathrm{FAK}$ on the $\mathrm{Gr}$ - reinforced sample (Figure 4K, $p<0.05$ ).

\section{Co-culture Model of Bacterial Multispecies and HGFs}

Previous studies focused more on a simple cell-bacteria coculture model consisting of the mono-factor. Currently, we redesigned the study to more closely resemble natural conditions, as showed in Figure 5. In the competition against bacterial multispecies, fewer HGFs covered the $\mathrm{Cp}$-Ti with wizened morphologies, while more robust HGFs grew on the Grreinforced sample. In terms of the cell coverage (\%), HGFs adhering to the Gr-reinforced surface increased at $24 \mathrm{~h}(p<0.01)$, implying that Ti-0.125G had the potential for enhancing soft tissue seal by benefiting the HGFs' viability in the presence of multispecies.

\section{DISCUSSION}

The current study fabricated a novel composite (Ti-0.125G) for the transmucosal profile and subsequently explored its dual effects regarding antibacteria and fast gingival attachment. Although better fibroblast adhesion is always in contradiction to less bacterial adhesion, the Gr-reinforced sample was expected to manipulate the "race-for-the-surface" between pathogenic multispecies and HGFs, thus to promote soft tissue integration in a pathogen-rich environment within transmucosal regions.

Reportedly, the SPS technique is more accessible to achieve large-scale productions (Rosa et al., 2012) and contributes to a robust bonding of $\mathrm{Ti}-0.125 \mathrm{G}$, since titanium atoms acts as electron donors and Gr acts as electron acceptors (Subbiah et al., 2014). Chemical vapor deposition (CVD) is the common technology that deposit single-layer graphene sheets on Ti disk. Reportedly, it may face the grim risk of layer peeling due to compromised adhesion strength between $\mathrm{Gr}$ and $\mathrm{Ti}$ surface (Gu et al., 2018). In contrast, for our material fabricated by SPS technology, which can largely offset the effect of layer peeling due to the strong bonding between graphene and Ti. As the temperature increases, the bonding strength between $\mathrm{Gr}$ and titanium increases ( $\mathrm{Hu}$ et al., 2017). In our study, the temperature elevated above $900^{\circ} \mathrm{C}$, Gr reacted with $\mathrm{Ti}$ and eventually became $\mathrm{TiC}$, improving the mechanical properties of the composites. Therefore, the elastic modulus and hardness of Ti-0.125G increased compared to Cp-Ti (Figures 1G,H). This advantages Ti-0.125G to be used as transmucosal appliances of the implant as the maximum stress was distributed at implant neck (Alvarez-Arenal et al., 2013), which requires a material with the better mechanical property. Currently, the surface roughness showed no significant variance after mixing with a small dose of

TABLE 3 | Numbers (expressed as the mean and standard error of the mean) of oral pathogens $\left[\times 10^{5}\right.$ colony-forming units $\left.(\mathrm{CFU}) / \mathrm{mL}\right]$ detected by absolute quantification PCR throughout the whole culturing duration on different samples, using specific primers and probes aimed to the 16S rRNA gene.

\begin{tabular}{lcccc}
\hline $\begin{array}{l}\text { Bacterial } \\
\text { species }\end{array}$ & $\begin{array}{c}\text { Incubation } \\
\text { time (hours) }\end{array}$ & Blank & Cp-Ti & Ti-0.125G \\
\cline { 3 - 5 } & \multicolumn{4}{c}{ Mean (SEM) (x 105 CFU/mL) } \\
\cline { 3 - 5 } S. mutans & $12 \mathrm{~h}$ & $53.6(12.2)$ & $29.3(11.1)$ & $15.1(3.7)$ \\
& $24 \mathrm{~h}$ & $29.1(3.2)$ & $34.5(2.8)$ & $23.2(7.3)$ \\
& $48 \mathrm{~h}$ & $35.4(6.9)$ & $15.4(9.7)$ & $8.0(0.4)$ \\
& $72 \mathrm{~h}$ & $19.6(6.9)$ & $9.5(1.2)$ & $6.7(1.6)$ \\
& $96 \mathrm{~h}$ & $14.7(4.5)$ & $11.3(3.4)$ & $4.7(1.4)$ \\
& $12 \mathrm{~h}$ & $120.9(67.3)$ & $138.7(32.5)$ & $53.4(33.8)$ \\
& $24 \mathrm{~h}$ & $279.7(101.9)$ & $319.8(80.0)$ & $138.9(71.3)$ \\
& $48 \mathrm{~h}$ & $304.5(176)$ & $102.3(46.0)$ & $4.7(1.0)$ \\
& $72 \mathrm{~h}$ & $147.7(33.3)$ & $21.3(9.0)$ & $2.6(1.0)$ \\
& $96 \mathrm{~h}$ & $177.7(161.5)$ & $8.2(2.8)$ & $1.6(0.4)$ \\
& $12 \mathrm{~h}$ & $157.4(127.3)$ & $121.3(52.8)$ & $77.13(32.47)$ \\
& $24 \mathrm{~h}$ & $324.3(246.0)$ & $373.2(210.4)$ & $46.76(17.99)$ \\
& $48 \mathrm{~h}$ & $336.2(262.5)$ & $193.1(91.2)$ & $4.2(3.2)$ \\
& $72 \mathrm{~h}$ & $315.6(244.3)$ & $27.1(16.9)$ & $4.2(2.9)$ \\
& $96 \mathrm{~h}$ & $294.0(206.0)$ & $10.6(5.0)$ & $0.4(0.2)$ \\
& & & &
\end{tabular}


A

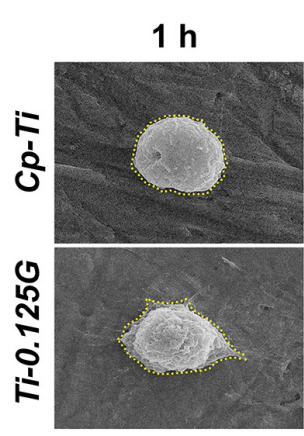

C $\frac{\mathscr{Q}}{x} \mathrm{Ma} / \mathrm{Mo}$ Elogation

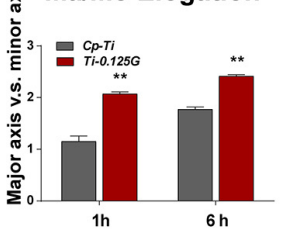

$6 \mathrm{~h}$
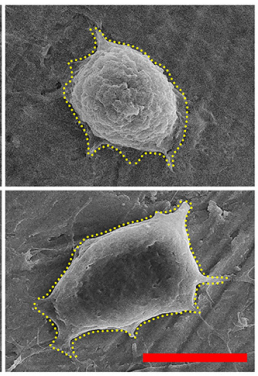

B

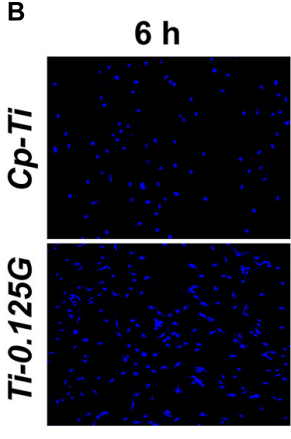

D Cell adhesion

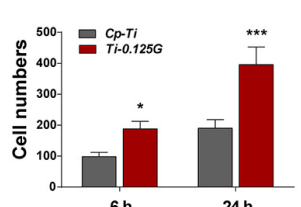

E Cell proliferation $F_{\bar{\sigma}} \quad$ Wound healing

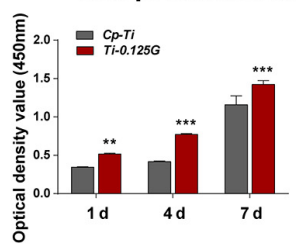

$24 \mathrm{~h}$
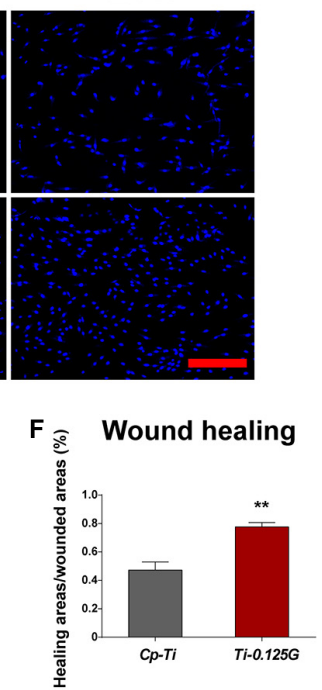
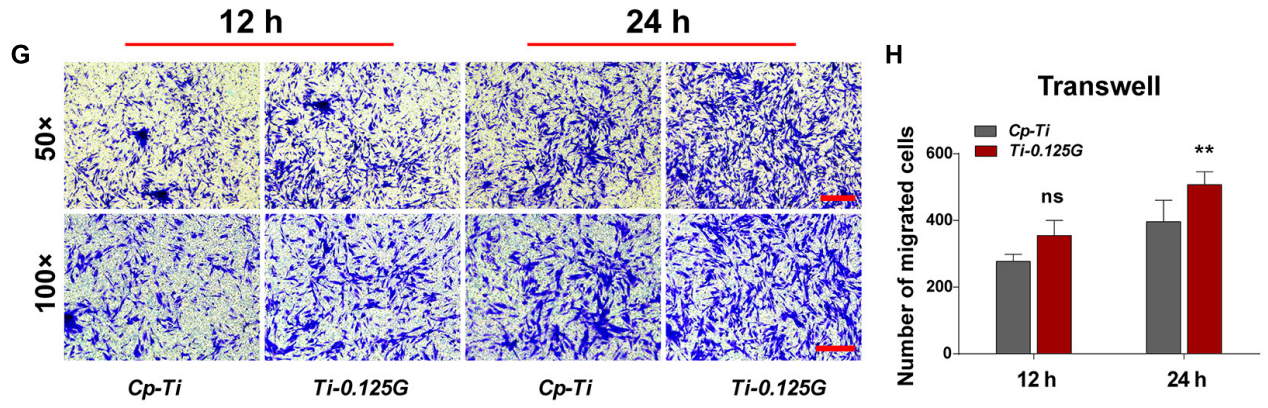

I

$6 \mathrm{~h}$
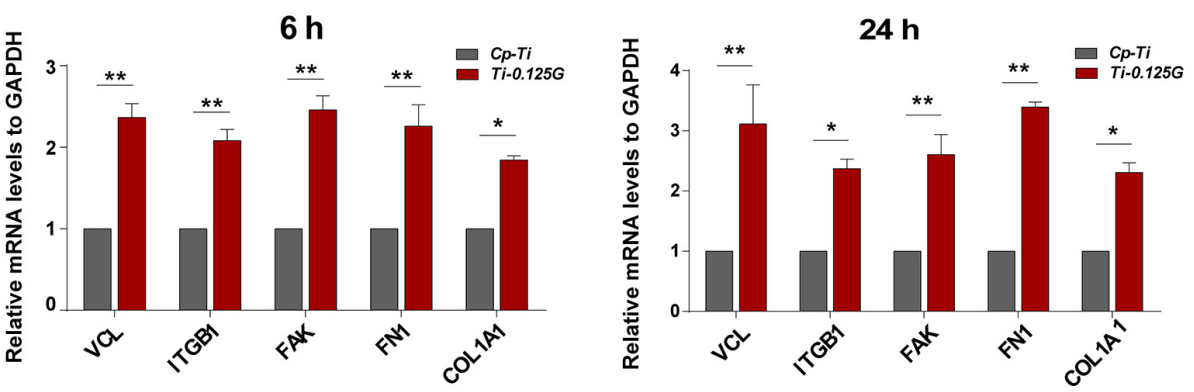

J

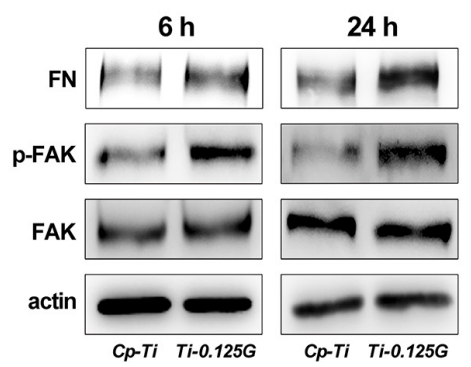

K

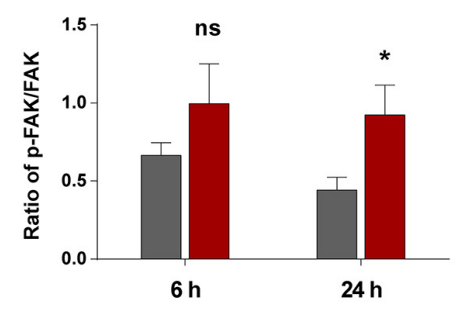

FIGURE 4 | HGFs Responses to the Sample. (A) SEM micrographs of HGFs on different samples at 1 and $6 \mathrm{~h}$. Scale bar = $5 \mu \mathrm{m}$. (B) Initial cell adhesions were observed at 6 and $24 \mathrm{~h}$ under CLSM. Scale bar $=250 \mu \mathrm{m}$. (C) Major axis/Minor axis of HGFs after 1 and $6 \mathrm{~h}$ of incubation (** $p<0.01$ ). (D) Statistical analysis of cell adhesion at the early stage $\left({ }^{\star} p<0.05,{ }^{\star \star \star} p<0.001\right)$. (E) HGFs proliferation properties on different samples were detected via CCK-8 for 1 , 4 , and 7 days $\left({ }^{\star \star} p<0.01,{ }^{* \star *} p<0.001\right)$. (F) Statistical analysis of wound healing assay ( $\left.{ }^{\star \star} p<0.01\right)$ at $24 \mathrm{~h}$. (G,H) Transwell assay at 12 and $24 \mathrm{~h}$ of incubation, CV-stained HGFs were counted as the migrated cells under the light microscope observation. Scale bar for $50 \times / 100 \times$ magnification $=200 \mu \mathrm{m})\left({ }^{\star \star} p<0.01\right)$. (I) Real-time PCR analyses of cell adhesion- and ECM component-related genes expression ( $\left.{ }^{\star} p<0.05,{ }^{\star \star} p<0.01\right)$. (J) Western blot analyses of signaling proteins, including $F A K$, $p-F A K$, and FN (K) Increased FN adsorption on Ti-0.125G ( $\left.{ }^{*} p<0.05\right)$. 

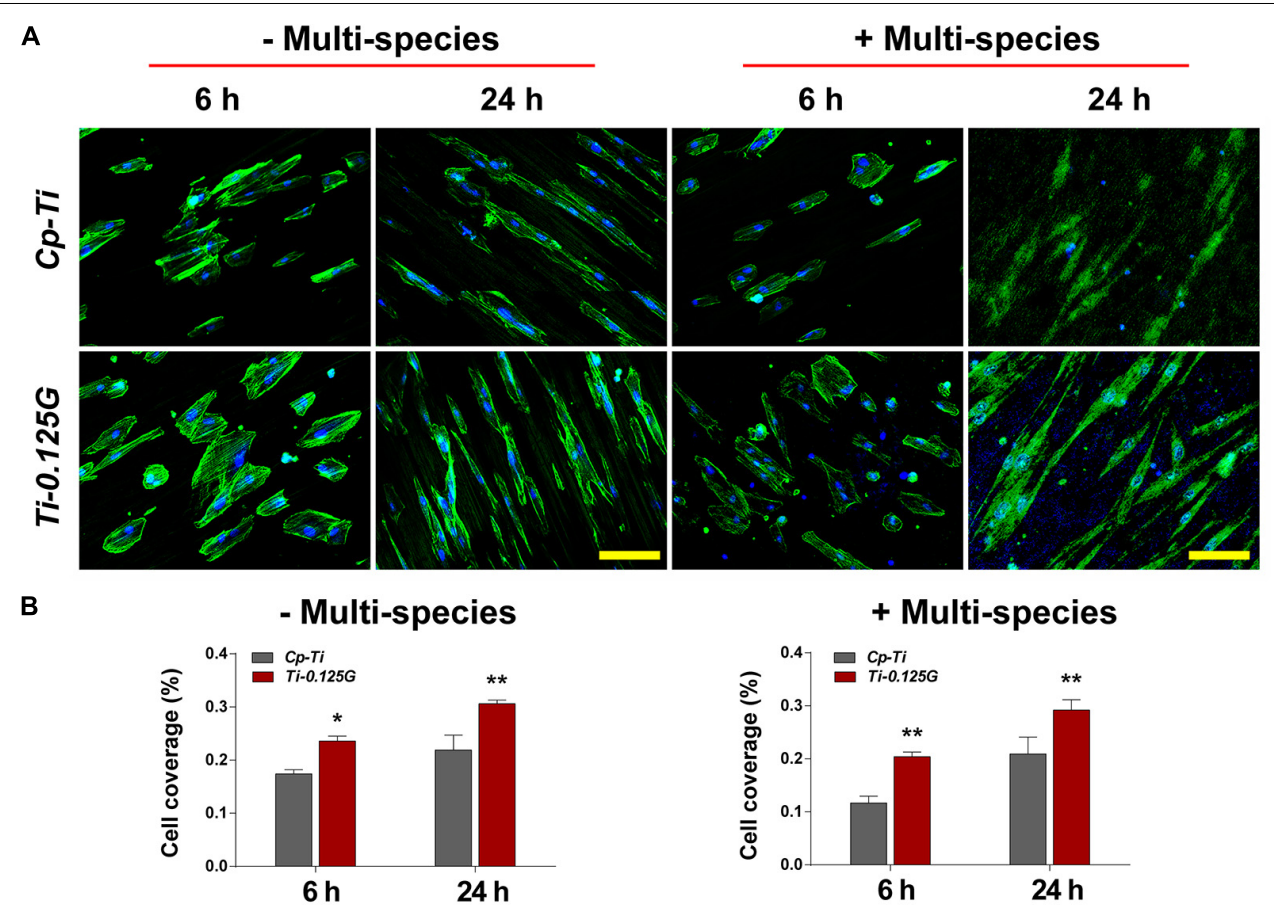

C

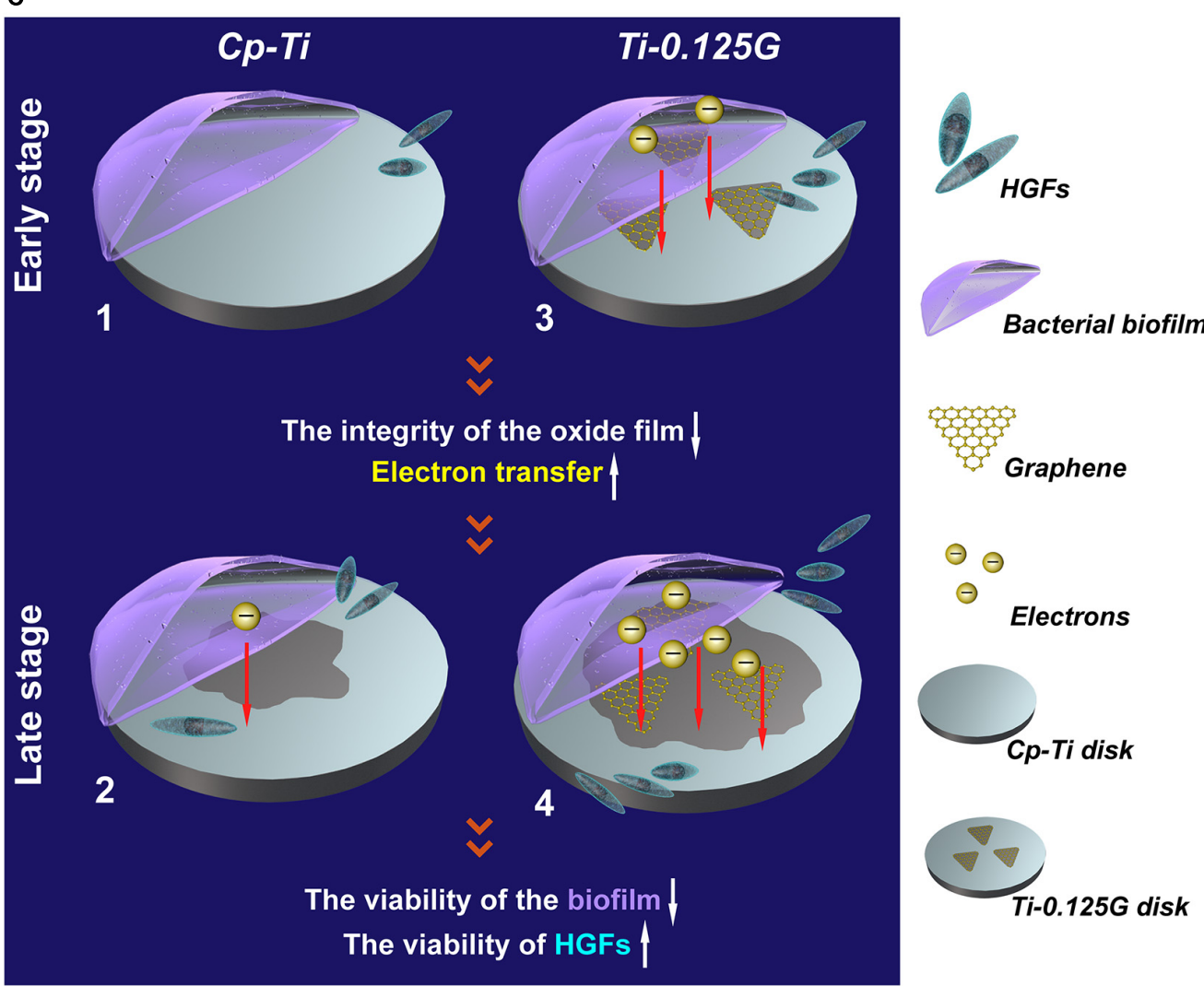

FIGURE 5 | The co-culture model of bacterial multispecies and HGFs. (A) CLSM images of HGFs seeded on different samples after 6 and $24 \mathrm{~h}$ of contamination by bacterial multispecies biofilms. The green and blue dyes marked the cytoskeleton and nuclei of HGFs, respectively. Scale bar $=100 \mu \mathrm{m}$. (B) Noted that cell coverage (\%) on Ti-0.125G increased as compared to the control ( $\left.{ }^{*} p<0.05,{ }^{* *} p<0.01\right)$. (C) Schematic circuitry of the proposed mechanism to clarify the bactericidal ability of the Gr-reinforced sample. (1) and (3) The primary stages of a "race-for-the-surface" between bacterial multispecies biofilms and HGFs on Cp-Ti and Ti-0.125G, respectively. (2) and (4) The late stages of a "race-for-the-surface" between bacterial multispecies biofilms and HGFs on Cp-Ti and Ti-0.125G, respectively. 
Gr (Figure 1I). In terms of the "race-for-the-surface," HGFs gain more advantages than oral pathogens as bacterial adhesion was inclined to reduce due to the surface roughness of Ti-0.125G was regarded as "minimally rough" $(\mathrm{Ra}<0.2 \mu \mathrm{m})$ (Albrektsson and Wennerberg, 2004; Jin et al., 2019).

Possessing sufficient antimicrobial property is desirable for an implant component in transmucosal regions. Ti-0.125G was found to destroy the intact structures of $S$. mutans, F. nucleatum, and $P$. gingivalis extensively, which refined earlier studies mainly focusing on a single gram-positive or negative pathogen (Akhavan et al., 2011; Zhou and Gao, 2014). Multispecies biofilm was reported to be mature after $96 \mathrm{~h}$ of adhering (Bermejo et al., 2019), posing a severe challenge since it compromised the integrity of soft tissue around implants. Herein, we gained a deeper understanding of the bactericidal effect of Ti-0.125G on multispecies biofilms in the first $96 \mathrm{~h}$. Given that the blank group inherently reproduced other biofilm models more than a one-off finding (Sánchez et al., 2011), the reliability of the results was ensured in the study. According to the analyses, Ti-0.125G exhibited an effective bactericidal potency against multiple pathogens broadly without suppressing one strain solely, in addition to its particular inhibitory effect on $P$. gingivalis at 96 h. The PICRUSt 2 predictions further deduced that its antimultispecies property might be related to the vanished pathway of "cell community-prokaryotes" in Ti-0.125G compared to the other groups (Figure 3D), implying that Ti-0.125G largely attenuated the synergistic effects between oral pathogens in multispecies biofilms (Lamont et al., 2002; Periasamy and Kolenbrander, 2009).

Apart from assessing the bactericidal potency, an ideal implant component was also expected to possess excellent bio-affinity and bio-activity. Previously, the Gr-induced biocompatibility was verified roundly in mesenchymal stem cells and periodontal ligament stem cells (Nayak et al., 2011; Xie et al., 2015). In the present study, Ti-0.125G was detected to motivate the viability, adhesion, and proliferation of HGFs in vitro, combined with stimulating HGFs' migration horizontally and vertically (Figure 4), which were crucial for protecting soft tissue integrity. ECM and integrins were also found to regulate soft tissue seal by activating FAK to trigger the downstream signals. Moreover, Ti-0.125G was investigated to activate the vinculin (VCL) and phosphorylate FAK, thus FN was deposited to promote HGFs' adhesion and mobility subsequently (Culp, 1978; Grinnell et al., 1980). Therefore, Ti-0.125G was recognized to enhance the histological integration of peri-implant soft tissue in vitro. Notably, the co-culture model of bacterial multispecies and HGFs was established to provide a more rigorous mimicry of the peri-implant environment. In the present model with multispecies invasion, Ti-0.125G contributed to the intact and distinct morphologies of HGFs (Figure 5A), indicating a stronger antibacterial potency than $\mathrm{Cp}$-Ti. Given the bioactivity aforementioned, Ti-0.125G had the dual effects of serving as a promising transmucosal application by simultaneously benefiting HGFs' responses and suppressing bacterial growth. This paved the way for preserving a competent soft tissue seal around implants.
Ultimately, an attempt had been made to explore the underlying mechanism of bactericidal property, which could be elucidated as a viewpoint of electron transfer from the bacterial biofilm to the sample (Figure 5C). To the best of our knowledge, once the extracellular region enhanced the uptake of electrons from bacterial membrane respiratory protein, microbes eventually lost their viability as lacking sufficient ATP to supply the respiratory chain (Hartshorne et al., 2009). In the current model, pathogens exhibited negative potentials in artificial saliva ( $\mathrm{pH}=5.6-7.6)$ because their isoelectric points (IP) were generally lower than the surrounding $\mathrm{pH}$, which formed the necessary condition for electron transfer. On the other hand, Gr was an ideal conductor and electron acceptor. TiC composite was also reported to facilitate electron transfer (Shen et al., 2015; Fu et al., 2017). Given the addition of Gr, it would be possible to break the integrity of the oxide film on $\mathrm{Cp}$-Ti surface, activating this poorly conductive surface into a metal-semiconductor surface. In this way, Gr activated the sample to receive more electrons by making it more sensitive to conductivity. Also, the Fermi level of Ti-0.125G surface decreased since Gr possessed a bandgap close to $0 \mathrm{eV}$ (Charlier et al., 2007). Hence, the facile transfer of electrons was achieved from the multispecies biofilm to the sample when the bacterial biofilm aligned its Fermi level with that of the Gr-reinforced substrate, which in turn lead to a decrease in microbial viability. Consequently, Ti-0.125G gained stronger resistance against multiple bacteria and won the "race-for-thesurface" to enhance soft tissue seal.

\section{CONCLUSION}

In conclusion, $\mathrm{Cp}$ - $\mathrm{Ti}$ and $\mathrm{Ti}-0.125 \mathrm{G}$ were synthesized using the spark plasma sintering (SPS) technique. In the current study, the antibacterial and biological properties of the samples were detected roundly. As compared to the control, Ti-0.125G was stronger to suppress the viability of bacterial multispecies biofilms (including S. mutans, F. nucleatum, and P. gingivalis) and activate HGFs bioactivity. The underlying mechanism of the bactericidal property might be summarized as the electron transfer from the bacterial multispecies biofilms to the $\mathrm{Gr}$ reinforced sample. The $16 \mathrm{~S}$ sequencing and PICRUSt 2 functional predictions provided some instructive results.

\section{DATA AVAILABILITY STATEMENT}

The data presented in the study are deposited in the Sequence Read Archive, accession number PRJNA70700.

\section{ETHICS STATEMENT}

The studies involving human participants were reviewed and approved by the Independent Ethics Committee of Shanghai Ninth People's Hospital affiliated to Shanghai Jiao Tong University School of Medicine No. YBKA201906. 
The patients/participants provided their written informed consent to participate in this study.

\section{AUTHOR CONTRIBUTIONS}

HL and JS contributed to the conception, design, data acquisition, analysis, and interpretation, and critically revised the manuscript. JW and SQ contributed to design, data acquisition, analysis, and interpretation, drafted, and critically revised the manuscript. $\mathrm{XZ}$ and YL contributed to data acquisition and analysis, critically revised the manuscript. $\mathrm{YZ}$ and $\mathrm{SW}$ contributed to interpretation, and drafted the manuscript. All authors gave final approval and agreed to be accountable for all aspects of the work.

\section{REFERENCES}

Akhavan, O., Ghaderi, E., and Esfandiar, A. (2011). Wrapping bacteria by graphene nanosheets for isolation from environment, reactivation by sonication, and inactivation by near-infrared irradiation. J. Phys. Chem. B 115, 6279-6288. doi: $10.1021 /$ jp200686k

Albrektsson, T., and Wennerberg, A. (2004). Oral implant surfaces: part 1-review focusing on topographic and chemical properties of different surfaces and in vivo responses to them. Int. J. Prosthodont. 17, 536-543.

Alvarez-Arenal, A., Segura-Mori, L., Gonzalez-Gonzalez, I., and Gago, A. (2013). Stress distribution in the abutment and retention screw of a single implant supporting a prosthesis with platform switching. Int. J. Oral Maxillofac. Implants 28, e112-e121. doi: 10.11607/jomi.2813

Bermejo, P., Sanchez, M. C., Llama-Palacios, A., Figuero, E., and Herrera, D. (2019). Topographic characterization of multispecies biofilms growing on dental implant surfaces: an in vitro model. Clin. Oral Implants Res. 30, 229-241. doi: 10.1111/clr.13409

Charlier, J.-C., Eklund, P., Zhu, J. and Ferrari, A. (2007). "Electron and phonon properties of graphene: their relationship with carbon nanotubes," in Carbon Nanotubes. Topics in Applied Physics. Vol 111, eds A. Jorio, G. Dresselhaus, and M.S. Dresselhaus (Berlin: Springer). doi: 10.1007/978-3-540-72865-8_21

Cheng, Y. F., Zhang, Q., Li, G. F., Xue, Y., Zheng, X. P., Cai, S., et al. (2019). Longterm effects of copper nanoparticles on granule-based denitrification systems: performance, microbial communities, functional genes and sludge properties. Bioresour. Technol. 289:121707. doi: 10.1016/j.biortech.2019.121707

Culp, L. (1978). Biochemical determinants of cell adhesion. Curr. Top. Membr. Transp. 11, 327-396. doi: 10.1016/S0070-2161(08)60752-2

Foss, B. L., Ghimire, N., Tang, R., Sun, Y., and Deng, Y. (2015). Bacteria and osteoblast adhesion to chitosan immobilized titanium surface: a race for the surface. Colloids Surf. B Biointerfaces 134, 370-376. doi: 10.1016/j.colsurfb.2015. 07.014

Fu, C., Li, M., Li, H., Li, C., Qu, C., and Yang, B. (2017). Fabrication of graphene/titanium carbide nanorod arrays for chemical sensor application. Mater. Sci. Eng. C Mater. Biol. Appl. 72, 425-432. doi: 10.1016/j.msec.2016.11. 089

Grinnell, F., Feld, M., and Minter, D. (1980). Fibroblast adhesion to fibrinogen and fibrin substrata: requirement for cold-insoluble globulin (plasma fibronectin). Cell 19, 517-525. doi: 10.1016/0092-8674(80)90526-7

Gu, M., Lv, L., Du, F., Niu, T., Chen, T., Xia, D., et al. (2018). Effects of thermal treatment on the adhesion strength and osteoinductive activity of single-layer graphene sheets on titanium substrates. Sci. Rep. 8:8141. doi: 10.1038/s41598018-26551-W

Hartshorne, R. S., Reardon, C. L., Ross, D., Nuester, J., Clarke, T. A., Gates, A. J., et al. (2009). Characterization of an electron conduit between bacteria and the extracellular environment. Proc. Natl. Acad. Sci. U. S. A. 106, 22169-22174. doi: 10.1073/pnas.0900086106

He, J., Zhu, X., Qi, Z., Aldalbahi, A., Shi, J., Song, S., et al. (2017). The inhibition effect of graphene oxide nanosheets on the development of Streptococcus

\section{FUNDING}

The materials in the current study were provided by Huan She. This study was financially supported by the National Natural Science Foundation of China (81771116 and 81600902), Shanghai Sailing Program (19YF1425900), and Fundamental Research Program Funding of Ninth People's Hospital affiliated to Shanghai Jiao Tong University School of Medicine (JYZZ102).

\section{SUPPLEMENTARY MATERIAL}

The Supplementary Material for this article can be found online at: https://www.frontiersin.org/articles/10.3389/fbioe. 2021.665305/full\#supplementary-material

mutans biofilms. Part. Part. Syst. Charact. 34:1700001. doi: 10.1002/ppsc. 201700001

Hu, Z., Chen, F., Xu, J., Ma, Z., Guo, H., Chen, C., et al. (2017). Fabricating graphene-titanium composites by laser sintering PVA bonding graphene titanium coating: microstructure and mechanical properties. Compos. B Eng. 134, 133-140. doi: 10.1016/j.compositesb.2017.09.069

Jia, Z., Shi, Y., Xiong, P., Zhou, W., Cheng, Y., Zheng, Y., et al. (2016). From solution to biointerface: graphene self-assemblies of varying lateral sizes and surface properties for biofilm control and osteodifferentiation. ACS Appl. Mater. Interfaces 8, 17151-17165. doi: 10.1021/acsami.6b05198

Jin, J., Fei, D., Zhang, Y., and Wang, Q. (2019). Functionalized titanium implant in regulating bacteria and cell response. Int. J. Nanomedicine 14, 1433-1450. doi: 10.2147/ijn.s193176

Lamont, R. J., El-Sabaeny, A., Park, Y., Cook, G. S., Costerton, J. W., and Demuth, D. R. (2002). Role of the Streptococcus gordonii SspB protein in the development of Porphyromonas gingivalis biofilms on streptococcal substrates. Microbiology 148(Pt 6), 1627-1636. doi: 10.1099/00221287-148-6-1627

Mellado-Valero, A., Buitrago-Vera, P., Sola-Ruiz, M. F., and Ferrer-Garcia, J. C. (2013). Decontamination of dental implant surface in peri-implantitis treatment: a literature review. Med. Oral Patol. Oral Cir. Bucal. 18, e869-e876. doi: $10.4317 /$ medoral.19420

Nayak, T., Andersen, H., Makam, V., Khaw, C., Bae, S., Xu, X., et al. (2011). Graphene for controlled and accelerated osteogenic differentiation of human mesenchymal stem cells. ACS Nano 5, 4670-4678. doi: 10.1021/nn200 $500 \mathrm{~h}$

Pereira, J., Tavares, F., Lima, K., Carreiro, A., Henriques, B., Silva, F., et al. (2015). Relation between dental implant joint surfaces and biofilm formation. Dentistry 5:296. doi: 10.4172/2161-1122.1000296

Periasamy, S., and Kolenbrander, P. E. (2009). Mutualistic biofilm communities develop with Porphyromonas gingivalis and initial, early, and late colonizers of enamel. J. Bacteriol. 191, 6804-6811. doi: 10.1128/jb.01006-09

Rosa, V., Della Bona, A., Cavalcanti, B. N., and Nör, J. E. (2012). Tissue engineering: from research to dental clinics. Dent. Mater. 28, 341-348. doi: 10.1016/j.dental. 2011.11.025

Sánchez, M. C., Llama-Palacios, A., Blanc, V., León, R., Herrera, D., and Sanz, M. (2011). Structure, viability and bacterial kinetics of an in vitro biofilm model using six bacteria from the subgingival microbiota. J. Periodontal. Res. 46, 252-260. doi: 10.1111/j.1600-0765.2010.01341.x

Sanchez, V. C., Jachak, A., Hurt, R. H., and Kane, A. B. (2012). Biological interactions of graphene-family nanomaterials: an interdisciplinary review. Chem. Res. Toxicol. 25, 15-34. doi: 10.1021/tx200339h

Schmidt, K., Auschill, T., Heumann, C., Frankenberger, R., Eick, S., Sculean, A., et al. (2016). Influence of different instrumentation modalities on the surface characteristics and biofilm formation on dental implant neck, in vitro. Clin. Oral Implants Res. 28, 483-490. doi: 10.1111/clr.12823

Shen, T., Zhou, X., Cao, H., Zheng, C., and Liu, Z. (2015). TiO2(B)-CNT-graphene ternary composite anode material for lithium ion batteries. RSC Adv. 5, 2244922454. doi: 10.1039/C5RA01337B 
Sridhar, S., Rodrigues, D. C., Abidi, Z., Wilson, T., Valderrama, P., Palmer, K., et al. (2016). In vitro evaluation of the effects of multiple oral factors on dental implants surfaces. J. Oral Implantol. 42, 248-257. doi: 10.1563/aaid-joi-D-1500165

Subbiah, R., Du, P., Van, A., Suhaeri, M., Hwang, M., Lee, K., et al. (2014). Fibronectin-tethered graphene oxide as an artificial matrix for osteogenesis. Biomed. Mater. 9:065003. doi: 10.1088/1748-6041/9/6/065003

Wang, J., Li, J., Guo, G., Wang, Q., Tang, J., Zhao, Y., et al. (2016). Silvernanoparticles-modified biomaterial surface resistant to staphylococcus: new insight into the antimicrobial action of silver. Sci. Rep. 6:32699. doi: 10.1038/ srep32699

Wang, X., Lu, T., Wen, J., Xu, L., Zeng, D., Wu, Q., et al. (2016). Selective responses of human gingival fibroblasts and bacteria on carbon fiber reinforced polyetheretherketone with multilevel nanostructured TiO2. Biomaterials 83, 207-218. doi: 10.1016/j.biomaterials.2016.01.001

Xie, H., Cao, T., Viana Gomes, J., Castro Neto, A., and Rosa, V. (2015). Two and three-dimensional graphene substrates to magnify osteogenic differentiation of periodontal ligament stem cells. Carbon 93, 266-275. doi: 10.1016/j.carbon. 2015.05.071

Yue, C., Kuijer, R., Kaper, H. J., van der Mei, H. C., and Busscher, H. J. (2014). Simultaneous interaction of bacteria and tissue cells with photocatalytically activated, anodized titanium surfaces. Biomaterials 35, 2580-2587. doi: 10.1016/ j.biomaterials.2013.12.036
Zhao, B., van der Mei, H. C., Subbiahdoss, G., de Vries, J., Rustema-Abbing, M., Kuijer, R., et al. (2014). Soft tissue integration versus early biofilm formation on different dental implant materials. Dent. Mater. 30, 716-727. doi: 10.1016/j. dental.2014.04.001

Zhou, R., and Gao, H. (2014). Cytotoxicity of graphene: recent advances and future perspective. Wiley Interdiscip. Rev. Nanomed. Nanobiotechnol. 6, 452-474. doi: 10.1002/wnan.1277

Zhu, B., Meng, H., Huang, B., Chen, Z., and Lu, R. (2019). Detection of T. forsythia and other important bacteria in crestal and subcrestal implants with ligature-induced peri-implant infection in dogs. J. Periodontol. 90, 306-313. doi: 10.1002/jper.18-0223

Conflict of Interest: The authors declare that the research was conducted in the absence of any commercial or financial relationships that could be construed as a potential conflict of interest.

Copyright $\odot 2021$ Wei, Qiao, Zhang, Li, Zhang, Wei, Shi and Lai. This is an openaccess article distributed under the terms of the Creative Commons Attribution License (CC BY). The use, distribution or reproduction in other forums is permitted, provided the original author(s) and the copyright owner(s) are credited and that the original publication in this journal is cited, in accordance with accepted academic practice. No use, distribution or reproduction is permitted which does not comply with these terms. 